\title{
Neuroprotection by Encephalomyelitis: Rescue of Mechanically Injured Neurons and Neurotrophin Production by CNS-Infiltrating T and Natural Killer Cells
}

\author{
H. Hammarberg, ${ }^{2}$ O. Lidman, ${ }^{1}$ C. Lundberg, ${ }^{1}$ S. Y. Eltayeb, ${ }^{1}$ A. W. Gielen, ${ }^{1}$ S. Muhallab, ${ }^{1}$ A. Svenningsson, ${ }^{1}$ \\ H. Lindå, ${ }^{3}$ P. H. van der Meide, ${ }^{4}$ S. Cullheim, ${ }^{2}$ T. Olsson, ${ }^{1}$ and F. Piehl ${ }^{1}$ \\ ${ }^{1}$ Department of Medicine, Neuroimmunology Unit, Karolinska Hospital, S171 76 Stockholm, Sweden, 2 Department of \\ Neuroscience, Karolinska Institute, S171 77 Stockholm, Sweden, ²Department of Neurology, Huddinge Hospital, S141 86 \\ Stockholm, Sweden, and ${ }^{4}$ Central Laboratory Animal Institute, Cytokine Biology Unit, Utrecht University, 3508 TD Utrecht, \\ The Netherlands
}

In experimental autoimmune encephalomyelitis (EAE), $\mathrm{CD}^{+}$ self-reactive T cells target myelin components of the CNS. However, the consequences of an autoaggressive $\mathrm{T}$ cell response against myelin for neurons are currently unknown. We herein demonstrate that EAE induced by active immunization with an encephalitogenic myelin basic protein peptide dramatically reduces the loss of spinal motoneurons after ventral root avulsion in rats. Both brain-derived neurotophic factor (BDNF)- and neurotrophin-3 (NT-3)-like immunoreactivities were detected in mainly T and natural killer (NK) cells in the spinal cord. In addition, very high levels of BDNF, NT-3, and glial cell line-derived neurotrophic factor mRNAs were present in T and NK cell populations infiltrating the CNS. Interestingly, bystander recruited NK and T cells displayed similar or higher neurotrophic factor levels compared with the EAE disease-driving encephalitogenic T cell population. High levels of tumor necrosis factor- $\alpha$ (TNF- $\alpha$ ) and interferon- $\gamma($ IFN- $\gamma$ ) mRNAs were also detected, and both these cytokines can be harmful to several types of CNS cells, including neurons. However, treatment of embryonic motoneuron cultures with TNF- $\alpha$ or IFN- $\gamma$ only had a deleterious effect in cultures deprived of neurotrophic factors. These results suggest that the potentially neurodamaging consequences of severe CNS inflammation are curbed by the production of several potent neurotrophic factors in leukocytes.

Key words: growth factors; neurotrophins; autoimmunity; axotomy; neurodegeneration; motoneuron
It is now well accepted that self-reactive $\mathrm{T}$ cells against central nervous tissue components under certain conditions can be harmful, because transfer of myelin basic protein (MBP) peptidereactive and activated $\mathrm{CD} 4^{+} \mathrm{T}$ cells to naive recipients causes experimental autoimmune encephalitis (EAE), with ensuing neurological deficits (Ben-Nun et al., 1981; Pettinelli and McFarlin, 1981). However, autoimmune T cells can also be innocuous, and it is at present unclear what features of the $\mathrm{T}$ cell function that determines encephalitogenicity. Thus, MBP-reactive T cells can be cloned also from healthy individuals and expand on nonspecific insults to the nervous system such as viral infections (Miller et al., 1997), stroke (Wang et al., 1992), and peripheral nerve trauma (Olsson et al., 1992, 1993). Autoimmunity can therefore be regarded as a normal phenomenon, which only under certain conditions is disease-promoting. Even if the traditional view has been that the relative immune privilege of the CNS serves to protect delicate neuronal networks from damage by immune reactions, recent evidence suggests that lymphocytes under some conditions may convey protective effects on neurons after mechanical nerve injuries. Thus, the loss of motoneurons after facial nerve transection in severe combined immunodeficient (scid) mice lacking functional $\mathrm{T}$ and $\mathrm{B}$ cells is aggravated compared with wild-type controls (Serpe et al., 1999). In another model of mechanical nerve injury, transfer of MBP-specific, but not ovalbumin-specific $\mathrm{T}$ cell lines rescues a proportion of the lesioned retinal ganglion cells after

\footnotetext{
Received Dec. 23, 1999; revised April 14, 2000; accepted April 26, 2000.

This work was supported by the Swedish Medical Research Council, Åke Wibergs stiftelse, Tore Nilsons stiftelse, Magnus Bergvalls stiftelse, NHR, David och Astrid Hageléns stiftelse, and Hjärnfonden. We thank Assoc. Prof. Robert A. Harris for expert advice and Dr. Giulia Arslan for help with confocal microscopy. The MC192 hybridoma was a kind gift from Drs. Ben Barres and Eric Shooter.

H.H., O.L., and C.L. contributed equally to this work

Correspondence should be addressed to Fredrik Piehl, Karolinska Institute, Department of Medicine, Neuroimmunology Unit, CMM L08;04, Karolinska Hospital, S171 76 Stockholm, Sweden. E-mail: Fredrik.Piehl@cmm.ki.se.

Copyright (c) 2000 Society for Neuroscience $0270-6474 / 00 / 205283-09 \$ 15.00 / 0$
}

optic nerve crush (Moalem et al., 1999). The mechanism or mechanisms by which lymphocytes increase survival of nerve cells under these conditions is currently unknown.

Adult motoneurons are more robust than those in the immature animal, and very little loss of motoneurons is evident after peripheral nerve injuries. However, after avulsion of ventral roots a large proportion of the lesioned motoneurons also degenerates in the adult animal (Koliatsos et al., 1994; Piehl et al., 1995a). Although several mechanisms may be involved in this type of neuronal degeneration, administration of brain-derived neurotrophic factor (BDNF) strongly enhances neuronal survival after ventral root avulsion (Novikov et al., 1995; Kishino et al., 1997), demonstrating that deprivation of neuronal growth factors is one of the major determinants of cell death in this injury model.

We herein explore the interaction between nerve cells and cells of the immune system, regarding effects on neuronal survival and expression of neurotrophic factors in the model of ventral root avulsion in adult rats. A concomitant active immunization with an encephalitogenic MBP peptide leads to a robust survivalpromoting effect on avulsed motoneurons in spite of a very intense inflammatory reaction with high levels of pro-inflammatory cytokines in the lesioned segments. Furthermore, the neuroantigenspecific immune response comprised the expression of several different neurotrophic factors by mainly bystander recruited $\mathrm{T}$ and NK cells. That neurotrophic factors produced by activated immune cells may constitute an important mechanism for neuronal protection in CNS inflammation is supported by the fact that interferon- $\gamma$ $(\mathrm{IFN}-\gamma)$ or tumor necrosis factor- $\alpha$ (TNF- $\alpha)$ treatment only resulted in increased death of cultured motoneurons in the absence of neurotrophic support.

\section{MATERIALS AND METHODS}

Induction of EAE. Adult rats from our in-house breeding facility (LEW.RT1 ${ }^{\mathrm{L}}$, LEW.RT1 ${ }^{\mathrm{AV} 1}$, and DA.RT1 ${ }^{\mathrm{AV} 1}$ ) were immunized with guinea pig $\mathrm{MBP}_{63-88}$ (AARTTHYGSLPQKSQRSQDENPVVHF) 
(Weissert et al., 1998). The rats were injected intradermally at the base of the tail with a total volume of $200 \mu \mathrm{l}$ of inoculum containing $100 \mu \mathrm{g}$ of MBP peptide in saline mixed with an equal volume of complete Freund's adjuvant (incomplete Freund's adjuvant, Sigma St. Louis, MO; and $1 \mathrm{mg}$ of heat-inactivated Mycobacterium tuberculosis, strain H37 RA, Difco Laboratories Detroit, MI). The animals were scored clinically and weighed on a daily basis. Symptoms were scored as follows: grade 1, tail weakness or tail paralysis; grade 2, hind leg paraparesis; grade 3, hind leg paralysis; and grade 4 , complete paralysis (tetraplegy).

Lesions. Adult immunized and nonimmunized rats were subjected to unilateral avulsion of the L3-L5 lumbar ventral roots as previously described (Piehl et al., 1999). This lesion results in an axotomy of all ipsilateral motoneurons in the lesioned segments. The removal of a long segment of the avulsed root makes functional reinnervation very improbable, at least within the time period studied here. Clinically the lesion leads to weakness in hip flexion and an almost complete paralysis in knee and ankle movements. No functional impairment of hind leg movements is observed on the unlesioned side, which means that the lesion does not interfere with the clinical scoring of EAE symptoms. In brief, a half-sided laminectomy was performed on the L3 vertebrae, and a longitudinal incision was made in the dural sac. The dorsal roots were carefully transposed to expose the L3-L5 lumbar ventral roots. Using a pair of fine, serrated tweezers the roots were delicately pulled caudally. The presence of rootlet subdivisions at the proximal tip was used as a verification that the root had been avulsed in the immediate vicinity of the spinal cord surface. As an additional control, the spinal cords were carefully examined using a dissection microscope after killing. Animals were killed with $\mathrm{CO}_{2}$ and perfused with cold PBS. Serial transverse sections $(14 \mu \mathrm{m})$ from inguinal lymph nodes and the L4 segment of the spinal cord were cut with a cryostat. The L3 segment in the experiment using DA rats was used for RT-PCR.

Delivery of recombinant IFN- $\gamma$ (van der Meide et al., 1986) was performed using mini-osmotic pumps (Alzet 2001; Alza Pharmaceuticals, Palo Alto, CA). A polyethylene tube connected to the pump was inserted through the laminectomy and inserted cranially in the vertebral canal $\sim 8$ $\mathrm{mm}$. The pump and tube were secured to surrounding tissues with sutures. The pumps were prefilled with either IFN- $\gamma$ dissolved in PBS $(200 \mu \mathrm{l}, 150$ $\mathrm{U} / \mu \mathrm{l}, 1 \mu \mathrm{l} / \mathrm{hr}$ ) or only PBS. Four rats were treated with IFN- $\gamma$ and four with saline, with a survival time of 1 week.

All animal experiments in this study were approved by the local ethical committee for animal experimentation (Stockholm North).

Cell counts. Cell counts were performed by a blind observer on cresyl violet-counterstained sections. Motoneurons were identified based on morphology and location in the ventral horn. Only cells with a visible nucleus and nucleolus were counted. No correction for split nucleoli was performed. Counts were made on every tenth section, mainly from the L4 segment, and a total of 15 sections from each rat were analyzed. The total number of motoneurons on lesioned and unlesioned sides, respectively, were used to calculate the percentage of surviving avulsed cells in each rat.

Immunohistochemistry. Sections were fixed in ice-cold acetone and $4 \%$ phosphate-buffered paraformaldehyde for $30 \mathrm{sec}$ each, washed in $0.01 \mathrm{M}$ PBS, preincubated with $2 \%$ horse serum for $30 \mathrm{~min}$, and then incubated overnight at $4^{\circ} \mathrm{C}$ with primary antisera diluted in PBS with $1 \%$ bovine serum albumin (BSA) and, when staining for neurotrophins, $0.2 \%$ Triton $\mathrm{X}-100$. The following antisera were used: anti-rat NKR-P1 (a marker for NK cells; clone 3.2.3; mouse IgG1; Harlan Sera-Lab, Loughborough, UK), anti-rat CD25 (clone OX-39; mouse IgG1; Serotec, Oxford, UK), anti-rat CD4 (clone W3/25; mouse IgG1; Serotec), anti-rat CD8 (clone OX-8; mouse IgG1; Serotec), anti-human glial fibrillary acidic protein (goat polyclonal IgG; Santa Cruz Biotechnology, Santa Cruz, CA), anti-rat CD11b (clone OX-42; mouse IgG2a; Serotec), anti-rat macrophage antigen (clone ED1; mouse IgG1; Serotec), anti-human NT-3, and BDNF (crossreacting with rat; rabbit polyclonal IgG; Santa Cruz Biotechnology). The second antibody step was performed with $\mathrm{Cy} 3$ - or $\mathrm{Cy} 2$-conjugated donkey anti-goat, donkey anti-mouse, or donkey anti-rabbit antisera, respectively (Jackson ImmunoResearch, West Grove, PA) for $30 \mathrm{~min}$ at $37^{\circ} \mathrm{C}$. The specificity of the immunostaining for NT-3 and BDNF was tested in control slides by incubation with pre-immune rabbit serum and preadsorption of the antibody with the respective peptides used as immunogens.

In situ hybridization. In situ hybridization was performed as previously described (Dagerlind et al., 1992; Hammarberg et al., 1998), using ${ }^{35}$ Slabeled 40-48 mer oligonucleotides. The probe sequences were complementary to mRNA encoding rat C3 complement (nucleotides 1095-1142) (Misumi et al., 1990), mouse glial fibrillary acidic protein (nucleotides 7863-7910) (Balcarek and Cowan, 1985), rat microglia response factor-1 (nucleotides 68-113) (Tanaka et al., 1998), rat TNF- $\alpha$ (nucleotides 24532406) (Shirai et al., 1989), rat IFN- $\gamma$ (nucleotides 351-392; GenBank accession number AF010466), rat BDNF (nucleotides 558-599 and 645694) (Maisonpierre et al., 1991), rat NT-3 (nucleotides 286-327 and 538-579) (Ernfors et al., 1990), and rat glial-derived neurotrophic factor (GDNF) (nucleotides 271-312 and 540-589) (Lin et al., 1993). In control sections, a 20 -fold excess of cold probe was added to the hybridization mixture. No labeling except for background was recorded in these cases. Furthermore, probes with similar length and $\mathrm{G} / \mathrm{C}$ content against unrelated mRNAs yielded nonoverlapping expression patterns. The two different probes against BDNF, NT-3, and GDNF, respectively, displayed similar hybridization patterns in adjacent sections.

Extraction of lymphocytes from lymph nodes and CNS. LEW.RT1 ${ }^{\mathrm{L}}$ rats (six rats immunized with MBP peptide $12 \mathrm{~d}$ after immunization and three healthy controls) were killed with $\mathrm{CO}_{2}$ and perfused with cold PBS. Brains and spinal cords were removed into 50\% Percoll (Amersham Pharmacia Biotech, Uppsala, Sweden $/ 0.1 \%$ BSA $/ 1 \%$ glucose. The CNS tissue was homogenized in $10 \mathrm{ml}$ of $50 \%$ Percoll containing $500 \mathrm{U}$ of DNase type I (Life Technologies, Täby, Sweden), using a B pistil and holder (Kontes, Vineland, NJ). Ten milliliters of 50\% Percoll were added to each sample after homogenization. A discontinuous Percoll gradient was obtained by adding $7 \mathrm{ml}$ of $63 \%$ Percoll below and $20 \mathrm{ml}$ of $30 \%$ Percoll above the sample. Samples were centrifuged for $30 \mathrm{~min}$ at $1000 \times g$ at $4^{\circ} \mathrm{C}$. Lymphocytes were collected from the $63 / 50 \%$ Percoll interface. The cells were subsequently washed twice in $15-25 \mathrm{ml}$ HBSS (Sigma)/0.1\% BSA $/ 1 \%$ glucose with centrifugation at $600 \times g$ for $15 \mathrm{~min}$ at $4^{\circ}$. Cells were counted, and viability was determined by Trypan blue dye exclusion.

Draining inguinal lymph nodes were dissected out into DMEM (Life Technologies). Cells were isolated by careful mechanical disruption of the lymph nodes. The cell suspension was washed twice in DMEM, resuspended in complete medium containing DMEM supplemented with $1 \%$ glutamine and 5\% fetal calf serum (Life Technologies), and flushed trough a $70 \mu \mathrm{m}$ plastic strainer (Falcon; Becton Dickinson, Mountain View, CA). Flow cytometric cell sorting. Monoclonal antibodies were purchased from PharMingen (San Diego, CA) and titred to optimal concentrations in preliminary experiments. Approximately $100 \mu \mathrm{l}$ of the cell suspensions derived from lymph nodes and CNS, respectively, were double-labeled with FITC-conjugated anti-rat $\alpha / \beta$ T cell receptor (TCRAB) and phycoerythrin (PE)-conjugated anti-rat $\mathrm{T}$ cell receptor $\mathrm{V} \beta \quad 8.2$ chain (TCRBV8S2) or V $\beta 10$ chain (TCRBV10) for the detection of encephalitogenic and nonencephalitogenic $\mathrm{T}$ cell subsets, respectively. Another panel of cells was stained with PE-conjugated anti-rat NKR-P1 (a NK cell marker) and FITC-conjugated TCRAB. The samples were incubated in the dark at $4^{\circ} \mathrm{C}$ for $20 \mathrm{~min}$, washed twice with PBS supplemented with $0.09 \% \mathrm{NaN}_{3}$ and $3 \%$ fetal calf serum, and resuspended in $500 \mu \mathrm{l}$ of PBS. The samples were subsequently analyzed on a fluorescence-activated cell sorter (FACS) (Becton Dickinson). One region (R1) was defined in the light scatter plot corresponding to live cells to eliminate cell debris in subsequent analysis, and one region (R2) delineated cells positive for the respective antibodies. Cell sorting was finally performed in exclusion mode with the sorting gate set as R1xR2. NK cells were collected as being NKR-P1 ${ }^{+} /$TCR AB $^{-}$. Approximately $2 \times 10^{4}$ cells of each subpopulation could be recovered in PBS in $50 \mathrm{ml}$ Falcon tubes precoated with BSA. The dilute cell suspensions were centrifuged at $400 \times g$ for $7 \mathrm{~min}$. The cell pellets were immediately frozen at $-70^{\circ} \mathrm{C}$ in the remaining $100 \mathrm{ml}$ of PBS until RNA extraction. In preliminary experiments, sorting purity was determined to be $>95 \%$, and recovery, including centrifugation steps, to be $30-40 \%$.

RT-PCR and quantitation of cytokine and neurotrophin $m R N A$ levels. Cytokine and neurotrophin mRNA levels were determined in DA rats $10 \mathrm{~d}$ after surgery (14 d after immunization) in lymph nodes and spinal cord. Each spinal cord sample consisted of contralateral and ipsilateral, respectively, ventral quadrants from the L3 segment from four animals. The samples were homogenized mechanically, and total RNA was extracted (total RNA extraction kit; Qiagen, Hilden, Germany). Reverse transcription was performed with $10 \mu \mathrm{l}$ of total RNA, random hexamer primers $(0.1$ $\mu \mathrm{g}$; Life Technologies), and Superscript reverse transcriptase (200 U; Life Technologies). Amplification was performed on an ABI Prism $7700 \mathrm{Se}-$ quence Detection System (Perkin-Elmer, Norwalk, CT) using the $5^{\prime} \mathrm{nu}-$ clease method (TaqMan) with a two-step PCR protocol $\left(95^{\circ} \mathrm{C}\right.$ for $10 \mathrm{~min}$ followed by 40 cycles of $95^{\circ} \mathrm{C}$ for $15 \mathrm{sec}$ and $60^{\circ} \mathrm{C}$ for $1 \mathrm{~min}$.). All primers and probes were designed with the Primer Express software (PerkinElmer; Table 1), except for $18 \mathrm{~S}$ rRNA (Perkin-Elmer). Amplification/ detection of contaminating genomic DNA was avoided by constructing either one of the primers or the TaqMan probe over an exon/intron boundary. The probes were labeled with FAM as reporter dye and TAMRA as quencher dye, except for the $18 \mathrm{~S}$ rRNA probe, which was labeled with JOE as reporter dye and TAMRA as quencher dye. Relative quantitation of mRNA levels was performed using the standard curve method, with amplification of mRNA and $18 \mathrm{~S}$ rRNA in separate tubes (described in detail in User Bulletin 2, Perkin-Elmer Applied Biosystems, 1997). The standard curves were created using three different dilutions (1, $1 / 100$, and $1 / 10000 \times$ ) of cDNA from concavalin A-stimulated rat lymph node cells (18 S rRNA, IFN- $\gamma$, TNF- $\alpha$, IL- $1 \beta)$ and axotomized rat sciatic nerve (BDNF, NT-3, and GDNF). By plotting the values for the threshold cycle (the first cycle in which the amount of amplicon exceeds the threshold) against the logarithm of the amount of input RNA (given by the dilution factor), a straight line was created. The highest and lowest values defined the range in which the amount of RNA in samples with unknown RNA amounts could be predicted. To not exceed the highest value of the standard curve for the neurotrophins, cDNA from FACS-sorted lymphocytes was used at a dilution of 1/10 compared with the cDNA standard. The samples were run in triplicates with primers and probes against $18 \mathrm{~S}$ rRNA and the target mRNA in the same PCR plate but in different wells. Samples without added cDNA served as negative controls. The relative amounts of $18 \mathrm{~S}$ rRNA and target mRNA in each sample could then be deduced from the $18 \mathrm{~S}$ rRNA and target mRNA standard curves, respectively. Finally, the 


\begin{tabular}{lll}
\hline Table 1. PCR primers and TaqMan probes \\
IFN- $\gamma$ & Forward & 5' TCGAATCGCACCTGATCACTA \\
& Reverse & 5' GGGTTGTTCACCTCGAACTTG \\
TNF- $\alpha$ & Probe & 5' CATCCTTTTTGCTTTACTGTTGCTGAAGAAG \\
& Forward & 5' GACCCTCACACTCAGATCATCTTCT \\
& Reverse & 5' ACGCTGGCTCAGCCACTC \\
IL-1 $\beta$ & Probe & 5' TAGCCCACGTCGTAGCAAACCACCAA \\
& Forward & 5' GAAAGACGGCACACCCACC \\
& Reverse & 5' AAACCGCTTTCCATCTTCTTCT \\
NT-3 & Probe & 5' TGCAGCTGGAGAGTGTGGATCCCAAAC \\
& Forward & 5' ACCATTCGAGATCTTACAGGTGAA \\
BDNF & Peverse & 5' TTGATCCATGTTGTTGCCTTG \\
& Fobe & 5' ATGTCCATCTTGTTTATGTGATATTTCTTGCTTATCTCC \\
& Reverse & 5' CCACAATGTTCCACCAGGTG \\
GDNF & Probe & 5' ACGGCGCAGCCTTCAT \\
& Forward & 5' GCCACCATCAAAAGACTGAAAAG \\
& Reverse & 5' CGGTTCCTCTCTCTTCGAGGA \\
& Probe & 5' TCACCAGATAAACAAGCGGCGGCA \\
\hline
\end{tabular}

Table 2. Clinical scores (see Materials and Methods) for animals immunized with guinea pig MBP $_{63-88}$ alone or in combination with VRA

\begin{tabular}{|c|c|c|c|c|c|c|c|}
\hline Strain & & $n$ & Survival p.i. (d) & $\begin{array}{l}\text { Median } \\
\text { cumulative score }\end{array}$ & $\mathrm{SD}$ & $\begin{array}{l}\text { Median } \\
\text { peak score }\end{array}$ & $\mathrm{SD}$ \\
\hline \multirow[t]{2}{*}{ LEW.RT1(av1) } & $\mathrm{EAE}+\mathrm{VRA}$ & 4 & 21 & 17 & 3.8 & 3 & 0.5 \\
\hline & EAE & 4 & & 16 & 1 & 3 & 0 \\
\hline \multirow{4}{*}{ DA.RT1(av1) } & $\mathrm{EAE}+\mathrm{VRA}$ & 4 & 14 & 9 & 2.5 & 3 & 0.5 \\
\hline & EAE & 4 & & 8.5 & 0.6 & 3 & 0 \\
\hline & $\mathrm{EAE}+\mathrm{VRA}$ & 4 & 24 & 7 & 3.8 & 3 & 1.2 \\
\hline & EAE & 4 & & 13 & 2.2 & 3 & 0 \\
\hline
\end{tabular}

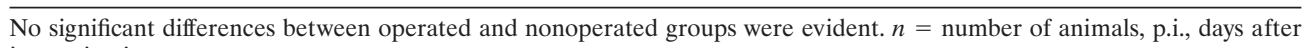
immunization.

amount of mRNA in each sample was calculated as the ratio between the relative amount of cytokine/neurotrophic factor and the relative amount of the corresponding endogenous control, $18 \mathrm{~S}$ rRNA.

Motoneuron cultures. Embryonic motoneuron cultures were prepared with an immunopanning procedure (Camu and Henderson, 1992). The protocol used in this study was adopted from Hughes et al. (1993) and Piehl et al. (1995b) and modified according to Hanson et al. (1998). Briefly, spinal cords from embryonic day 15 rats (Sprague Dawley; BK Universal, Sollentuna, Sweden) were removed and dissected free of meninges. The lumbar ventral columns were isolated, trypsinized, and triturated. The resulting cell suspension was filtered and separated by centrifugation on a metrizamide $(6.8 \mathrm{mg} / \mathrm{ml}$; Sigma) density gradient. Large, low-density cells were collected and further enriched by immunopanning as previously described (Piehl et al., 1995b). Cells were seeded onto 24 well cell culture dishes (Costar, Cambridge, MA) precoated with poly-DL-ornithine and laminin at a density of 200-300 neurons $/ \mathrm{cm}^{2}$ in serum-free medium (Piehl et al., 1995b). Cultures were incubated at $37^{\circ} \mathrm{C}$ with $5 \% \mathrm{CO}_{2}$ for $1 \mathrm{hr}$ before initiating treatments. The purity of the cultures was evaluated with the neuron-specific antibody MAP-2 (clone HM-2; Sigma) and the motoneuron-specific antibodies Islet-1 (clone 2D6; Developmental Studies Hybridoma Bank, Iowa City, IA) (Ericson et al., 1992) and low-affinity neurotrophin receptor (LANR; clone MC 192) (Chandler et al., 1984). More than $99.5 \%$ of the cells were positive for MAP-2, 94\% were positive for LANR, and $88.5 \%$ were positive for Islet-1. Cells were treated with rat recombinant IFN- $\gamma(1,10$, or $100 \mathrm{U} / \mathrm{ml}$ ) (van der Meide et al., 1986) or rat recombinant TNF- $\alpha$ (0.1 or $10 \mathrm{ng} / \mathrm{ml}$; Peprotech EC, London, UK) in the following paradigms: serum-free medium alone, neurotrophic factors (human recombinant BDNF $10 \mathrm{ng} / \mathrm{ml}$, human recombinant NT-3 $20 \mathrm{ng} / \mathrm{ml}$, human recombinant GDNF $1 \mathrm{ng} / \mathrm{ml}$, and rat recombinant CNTF $10 \mathrm{ng} / \mathrm{ml}$; Peprotech EC) or both $2 \%$ horse serum (Life Technologies) and neurotrophic factors as above. New media and factors were added daily. Survival was analyzed $2 \mathrm{~d}$ after plating as previously described (Hanson et al., 1998). Thus, living cultures were incubated with MTT (Sigma) for $1 \mathrm{hr}$, fixed in $4 \%$ paraformaldehyde, and evaluated blindly. The number of viable cells was divided by the total number of dead and living cells, yielding a survival ratio. The survival ratios for different treatments are composed of pooled data from three different cultures, each consisting of four wells for each treatment combination.

\section{RESULTS}

\section{Survival of lesioned motoneurons}

In a first set of experiments we studied the effects of ventral root avulsion and concomitant EAE in LEW.RT ${ }^{\mathrm{AV} 1}$ rats, with immunization taking place the day before surgery. The cumulative score of EAE clinical signs in operated and nonoperated groups did not differ (Table 2), suggesting that the surgery did not discernibly interfere with the immune response against the MBP peptide. All rats were in remission by day 14 after surgery ( $15 \mathrm{~d}$ after immunization). Survival of motoneurons was analyzed $20 \mathrm{~d}$ after surgery (21 d after immunization) and revealed a 50\% higher survival rate in immunized animals compared with control animals (Table 3). Immunohistochemical analysis of inflammatory cells demonstrated a moderate number of cells labeled with $\mathrm{T}$ or $\mathrm{NK}$ cell markers in the spinal cord, whereas ED1 staining for macrophages and markers for glia activation were grossly enhanced. In nonimmunized animals, staining for ED1 was present mainly in phagocytic microglia solely in the ventral horn of the avulsed side. No or only occasional T and NK (or NK-T) cells could be detected in these animals. Because this first experiment suggested that concomitant EAE induction reduces the degeneration of motoneurons, we analyzed the outcome in another inbred rat strain, DA.RT ${ }^{\text {AV1 }}$. This particular strain suffers from a greater loss of motoneurons after nerve avulsion injury than the LEW.RT ${ }^{\mathrm{AV} 1}$ strain (C. Lundberg and F. Piehl, unpublished observation), and the onset of motoneuron loss in the DA strain has been established to occur around day 7 after surgery (Piehl et al., 1999). To match the onset of EAE with that of neurodegeneration, animals were immunized $4 \mathrm{~d}$ before surgery. Two time points were analyzed, $10 \mathrm{~d}$ after surgery (14 d 


\begin{tabular}{|c|c|c|c|c|c|c|}
\hline Strain & $\begin{array}{l}\text { Postoperative } \\
\text { survival (d) }\end{array}$ & & & $\begin{array}{l}\text { Motoneuron } \\
\text { numbers }\end{array}$ & $\mathrm{SD}$ & $\begin{array}{l}\text { Survival } \\
\text { IL/CL }(\%)\end{array}$ \\
\hline \multirow[t]{4}{*}{ LEW.RT1(av1) } & 20 & VRA & IL & 77 & 7.3 & 40 \\
\hline & & & $\mathrm{CL}$ & 193 & 7.1 & \\
\hline & & $\mathrm{EAE}+\mathrm{VRA}$ & IL & 101 & 9 & 54 \\
\hline & & & $\mathrm{CL}$ & 187 & 11.3 & \\
\hline \multirow[t]{8}{*}{ DA.RT1(av1) } & 10 & VRA & IL & 93 & 5.7 & 48 \\
\hline & & & $\mathrm{CL}$ & 195 & 22 & \\
\hline & & $\mathrm{EAE}+\mathrm{VRA}$ & IL & 136 & 7.2 & 71 \\
\hline & & & $\mathrm{CL}$ & 191 & 15.6 & \\
\hline & 20 & VRA & $\mathrm{IL}$ & 38 & 5.6 & 19 \\
\hline & & & $\mathrm{CL}$ & 205 & 13.3 & \\
\hline & & $\mathrm{EAE}+\mathrm{VRA}$ & IL & 81 & 8.1 & 41 \\
\hline & & & $\mathrm{CL}$ & 198 & 10.1 & \\
\hline
\end{tabular}

The survival is significantly increased after concomitant EAE $(p<0.05$, Mann-Whitney $U$ test $)$ in both the LEW and DA strains. The difference in motoneuron survival after VRA alone between the LEW and DA strains concurs with our previous observations regarding a genetic influence on the degree of motoneuron degeneration in this lesion model (see Results). $n=4$ animals in each group. IL, ipsilateral; CL, contralateral.

Figure 1. Hematoxylin counterstaining of the L4 segment reveals higher density of small-sized nuclei in the lesioned ventral horn. $A$, After only ventral root avulsion these nuclei almost entirely consist of proliferating glia (see Results). $B$, In combination with EAE, the glia proliferation is also accompanied by an extensive infiltration of leukocytes (14 d after immunization). The boxed areas in $A$ and $B$ are shown in higher magnification in $C$ and $D$. Note the presence of higher numbers of surviving motoneurons in the immunized animal $(C, D$, arrowheads). Scale bar, $1 \mathrm{~mm}$.
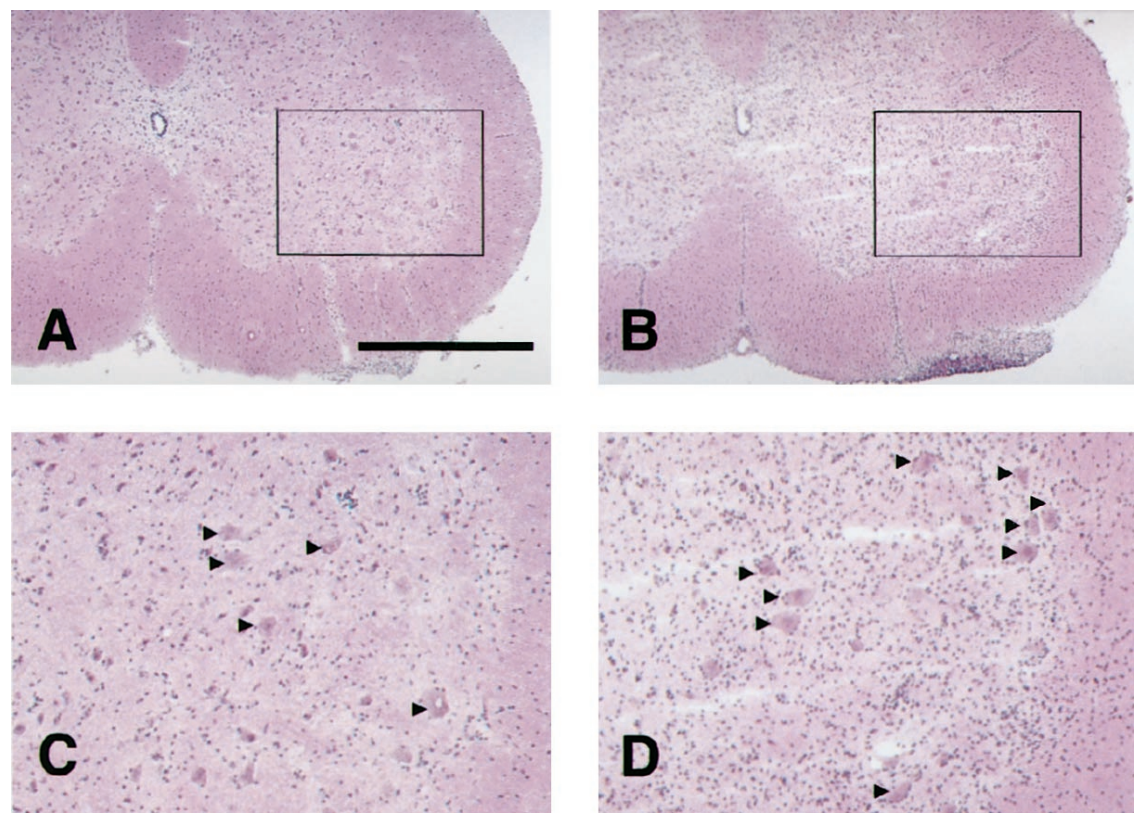

after immunization) and $20 \mathrm{~d}$ after surgery (24 d after immunization). In agreement with the first experiment, cumulative scores did not differ significantly between operated and nonoperated animals (Table 2). Cell counts in the DA.RT ${ }^{\mathrm{AV} 1}$ strain confirmed the neuroprotective effect of simultaneous EAE observed in LEW.RT ${ }^{\mathrm{AV} 1}$, because 50\% (14 d after immunization) and $120 \%$ (24 d after immunization) more of the avulsed motoneurons remained in immunized animals compared with nonimmunized controls (Table 3).

Sections counterstained with hematoxylin demonstrated extensive infiltration of inflammatory cells in immunized and operated animals, whereas few such cells were evident in only operated animals (Fig. 1). Immunohistochemically the inflammatory cell infiltrates comprised large numbers of T and NK cells (see Fig. 3) and macrophages. Inflammatory parameters, such as expression of complement $\mathrm{C} 3$, glial fibrillary acidic protein, and microglia response factor- 1 mRNAs and levels of IL- $1 \beta$, IFN- $\gamma$, and TNF- $\alpha$ mRNAs (Fig. $2 A, B$ ), demonstrated intense activation in the lesioned segments of immunized and operated animals. Interestingly, the levels of inflammatory cytokines were higher on the contralateral compared with operated side, a finding that was reproduced also in an independent control experiment (data not shown). Still lower levels of inflammatory cytokines were recorded in immunized, but not operated animals. Expression of glial activation markers was upregulated in the ventral horn after avulsion, although very little induction of cytokine mRNAs was evident (Fig. $2 A, B)$.

\section{Expression of neuronal growth factors in lymph nodes and CNS}

In situ hybridization for neurotrophic factor mRNAs revealed very intense labeling in draining inguinal lymph nodes from immunized animals (see Fig. 4). The hybridization pattern for NT-3 and BDNF was largely overlapping with that of IFN- $\gamma$ and TNF- $\alpha$, whereas fewer cells were positive for GDNF mRNA. Cells expressing NT-3, BDNF, or GDNF, as well as occasional IFN- $\gamma$ - or TNF- $\alpha$-positive cells, were also present in lymph nodes from nonimmunized animals. By double-labeling immunofluorecence histochemistry, NT-3 and BDNF could be localized to activated T cells in the reactive lymph nodes. Another population of cells that displayed intense neurotrophin immunoreactivity in lymph nodes was double-labeled with the NK cell marker. Relative quantitation 

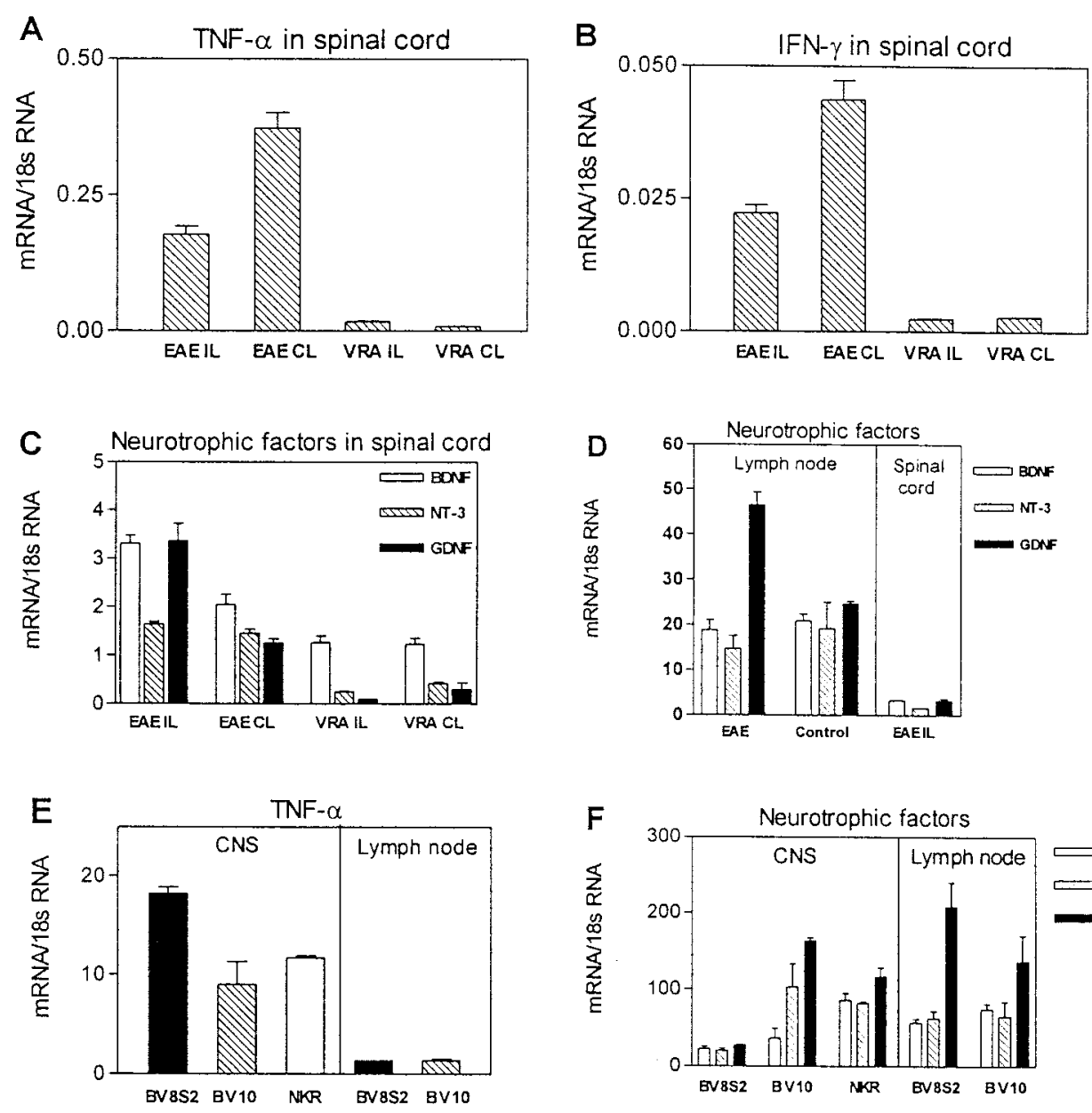

Figure 2. Expression of cytokines and neurotrophic factors in spinal cord, lymph nodes, and FACS-sorted cell populations. $A, B$, Highly elevated mRNA levels of the proinflammatory cytokines $\mathrm{TNF}-\alpha$ and IFN- $\gamma$ are present in the spinal cord of immunized and operated DA rats during active EAE, but not after injury alone. $C$, Relative quantification of neurotrophin mRNAs demonstrate much higher levels in the spinal cords of immunized animals compared with solely operated animals. $D$, A moderate induction of GDNF mRNA, but not BDNF and NT-3 mRNAs, is present in lymph nodes from immunized animals. Note differences in the relative levels of neurotrophic factors in lymph nodes and spinal cords. $E$, Cells sampled from the CNS of LEWRT ${ }^{\mathrm{L}}$ rats during active EAE display highly elevated levels of TNF- $\alpha$ mRNA compared with control cells from lymph nodes of nonimmunized animals. A relatively stronger induction is evident in the TCRBV8S $2^{+}$population. $F$, High levels of neurotrophic factor transcripts are present in leukocyte populations from both immunized and nonimmunized animals. Notably, the TCRBV8S2 ${ }^{+}$population displays a conspicuous downregulation of the expression of trophic factors compared with the TCRBV $10^{+}$and NKR-P1 ${ }^{+}$populations. $E A E$, Experimental autoimmune encephalomyelitis; $V R A$, ventral root avulsion; $I L$, ipsilateral; $C L$, contralateral. of mRNA levels with RT-PCR demonstrated some degree of induction of GDNF in lymph nodes of immunized animals (Fig. $2 D$ ). In contrast, NT-3 and BDNF mRNA levels normalized to the content of ribosomal RNA were similar in lymph nodes from immunized and control animals, respectively (Fig. 2D).

Expression of neurotrophin mRNAs was also detected with in situ hybridization in the spinal cord, but the labeling intensity was weaker than in lymph nodes. Both BDNF and NT-3 revealed a diffuse hybridization pattern throughout the parenchyma in immunized animals. In contrast, very low signals were present in operated and nonoperated controls. No positive labeling for GDNF mRNA could be demonstrated. These findings were corroborated by the assessment of neurotrophin mRNA levels by RT-PCR. All three transcripts displayed 2- to 10-fold higher levels in operated and immunized animals compared with solely operated animals (Fig. 2C). Notably, however, the levels of mRNA for neurotrophic factors were approximately 10 -fold higher in lymph nodes compared with spinal cord (Fig. 2D). These RT-PCR data were reproduced in an independent experiment (data not shown). Antibody labeling for NT-3 and BDNF demonstrated a extensive infiltration of immunopositive cells in the spinal cords of immunized animals and the most intensely NT-3- and BDNF-labeled cells were also stained with markers for T and NK cells (Fig. 3).

\section{Flow cytometric sorting of cells from CNS and lymph nodes}

A question that arises from the data presented above regards the nature of the $\mathrm{T}$ cells present in the CNS after immunization and whether these cells belong to an encephalitogenic population. To address this question we performed an experiment involving the collection and subsequent FACS-sorting of inflammatory cells directly from CNS tissue of immunized animals. This experiment was performed in the LEW.RT1 ${ }^{\mathrm{L}}$ strain, because immunization with $\mathrm{MBP}_{63-88}$ leads to an expansion of a TCRBV8S2 ${ }^{+} \mathrm{T}$ cell population that drives the disease (Tsuchida et al., 1993; Imrich et al., 1995; Weissert et al., 1998). TCRBV10 ${ }^{+}$T cells and NK cells collected from the CNS of immunized animals and TCRBV8S $2^{+}$ and $\mathrm{TCRBV}^{+}{ }^{+} \mathrm{T}$ cells collected from lymph nodes of control animals were analyzed in parallel, because very low numbers of $\mathrm{T}$ cells were obtained from the CNS of nonimmunized animals. Relative quantification of the mRNA levels in the different populations demonstrated a 10-fold induction of TNF- $\alpha$ mRNA in the TCRBV8S2 ${ }^{+}$population obtained from the CNS of EAE animals compared with TCRBV8S $2^{+}$cells from lymph nodes of control animals (Fig. $2 E$ ). TNF- $\alpha$ induction after immunization, although to a lower degree, was also present in the $\mathrm{TCRBV} 10^{+}$population (Fig. 2E). Analysis of the expression of neurotrophic factors revealed very high levels in the sorted cells. Normalized to the content of ribosomal RNA, the levels were 50- to 200-fold higher than in whole segments of CNS tissue. TCRBV8S2 ${ }^{+}$and $\mathrm{BV} 10^{+}$ cells from lymph nodes of control animals displayed almost identical levels of NT-3, BDNF, and GDNF mRNA. Although the levels of these transcripts in TCRBV $10^{+}$cells sorted from the CNS of immunized animals and lymph nodes of control animals, respectively, did not differ discernibly, the expression of neurotrophic factors in activated TCRBV8S2 ${ }^{+}$cells was downregulated. However, in an independent experiment using TCRAB ${ }^{+}$TCRBV8S2 $^{-}$ cells as a control population instead of $\mathrm{TCRBV} 10^{+}$cells, this difference was less pronounced (data not shown). Furthermore, the levels of neurotrophin mRNAs were higher in cells obtained from CNS compared with cells obtained from lymph nodes of nonimmunized animals. We also have preliminary data demonstrating a dynamic regulation of the neurotrophin expression in CNSinfiltrating lymphocytes during the course of EAE (C. Lundberg, S. Muhallab, F. Piehl, and T. Olsson, unpublished observation), 

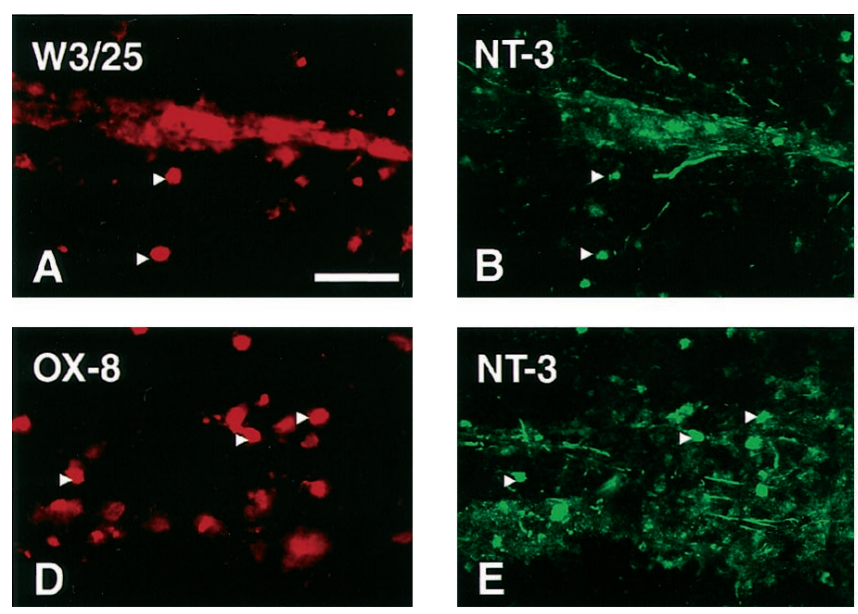

Figure 3. Immunohistochemical colocalization of neurotrophins and leukocyte markers $(C, F, I, L$, yellow) in spinal cord sections from immunized animals $(14 \mathrm{~d}$ after immunization) subjected to ventral root avulsion. The depicted cells are located in the ventral horn of the lesioned side. Examples of double-labeled cells are indicated by arrowheads in $A-L$. The NT-3 immunolabeling displays a high degree of colocalization with W3/25 $\left(\mathrm{CD} 4{ }^{+}\right)(A-C), \mathrm{OX} 8\left(\mathrm{CD}^{+}\right)(D-F)$, and NKR-P1 (NK cells) ( $G-I)$-labeled cells. The immunolabeling for BDNF is more diff use and does not colocalize to cells to the same degree as NT-3. However, a moderate number of W3/25-labeled cells also display positive BDNF staining ( $J_{-}$ $L)$. Only very weak immunofluorescence is seen in control sections where the primary antibody was pre-absorbed with the corresponding peptide for NT-3 and BDNF, respectively ( $M$ and $N$ display double labeling with W3/25). Scale bar, $0.05 \mathrm{~mm}$.
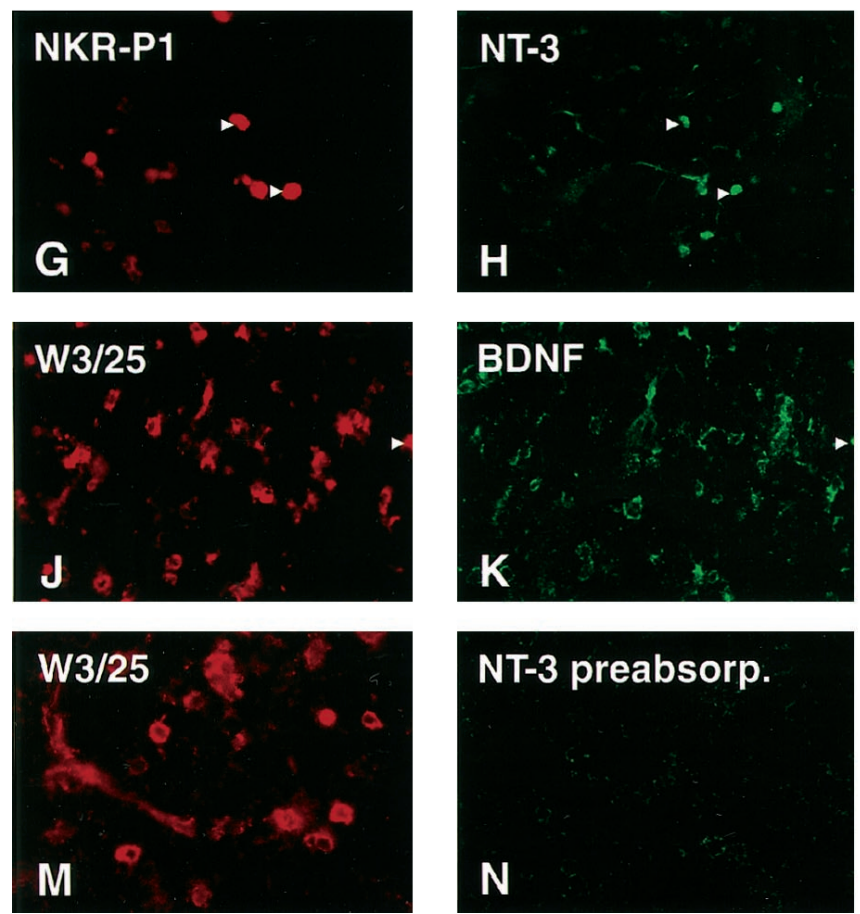
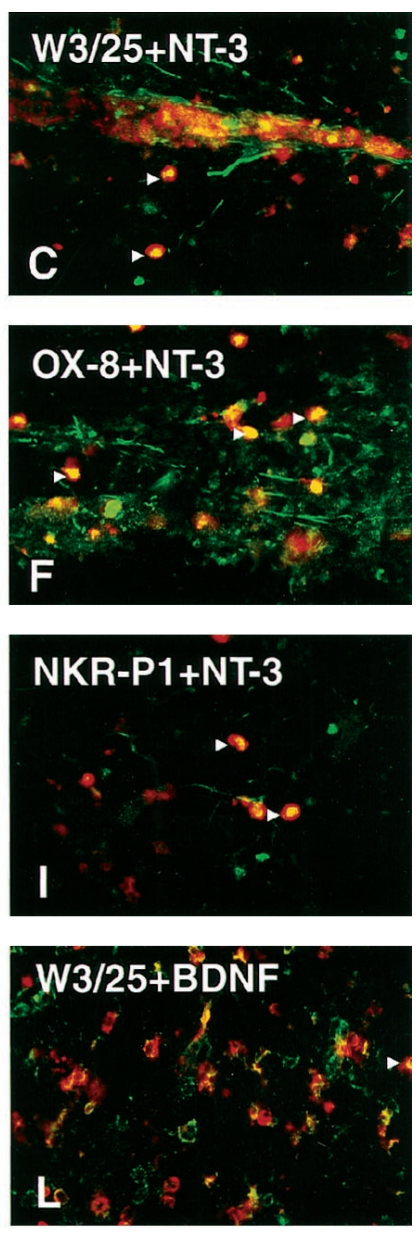

BDNF preabsorp.

0 suggesting that these differences to a large degree depends on when during the disease course the cells are sampled. Nevertheless, one of the most interesting observations is that the neurotrophin expression in infiltrating lymphocytes does not seem to be correlated to the general state of cellular activation as judged by the levels of TNF- $\alpha$ mRNA and that the bystander recruited cells contain similar or higher levels of neurotrophin mRNAs.

\section{Effect of IFN- $\gamma$ and TNF- $\alpha$ in embryonic motoneuron cultures}

IFN- $\gamma$ and TNF- $\alpha$ were highly induced in the lesioned segments, and both substances are known to induce death of certain CNS cell populations, including neurons (Louis et al., 1993; Talley et al., 1995; Vartanian et al., 1995). We examined the effects of proinflammatory cytokines on primary motoneuron cultures established from embryonic day 15 rats and enriched by density centrif ugation and immunopanning. Motoneurons were cultured under three different conditions: in serum and neurotrophic factor-supplemented medium, in medium supplemented with neurotrophic factors alone, or without serum/neurotrophic factors. Cultures were treated with recombinant IFN- $\gamma$ or TNF- $\alpha$ at different concentrations. Cytokine treatment did not have any discernible effects on the survival of cells cultured in medium supplemented with serum/neurotrophic factors. In contrast, both IFN- $\gamma$ or TNF- $\alpha$ treatment resulted in a dose-dependent reduction of survival in cultures deprived of neurotrophic support (Fig. 5). These results demonstrate that both IFN- $\gamma$ and TNF- $\alpha$ have detrimental effects on motoneurons in vitro, but that this effect can be blocked by neurotrophic factors.

\section{In vivo administration of IFN- $\gamma$}

Proinflammatory cytokines such as IFN- $\gamma$ and TNF- $\alpha$ potently activate both astrocytes and microglia, and expression of neurotrophic factors has been demonstrated in activated glia (Elkabes et al., 1996). To examine the possibility that increased IFN- $\gamma$ levels may exert a neuroprotective effect mediated via stimulation of neurotrophic factor production in glia, we administered high doses of IFN- $\gamma$ with mini-osmotic pumps to animals subjected to ventral root avulsion. The infusion of IFN- $\gamma$ resulted in a vigorous activation of mainly microglia throughout the parenchyma of lumbar and thoracic parts of the spinal cord, with highly induced expression of microglia response factor- 1 and complement C3 mRNAs, whereas no glial activation was evident in PBS-treated animals. However, both the in situ hybridization and immunolabeling patterns for BDNF and NT-3 within the CNS parenchyma did not differ between IFN- $\gamma$-treated and control animals (data not shown). However, there was a certain recruitment of T or NK cells to the meninges. A proportion of these cells, mostly NK cells, was also immunopositive for NT-3. Thus, activation of glia by IFN- $\gamma$ 

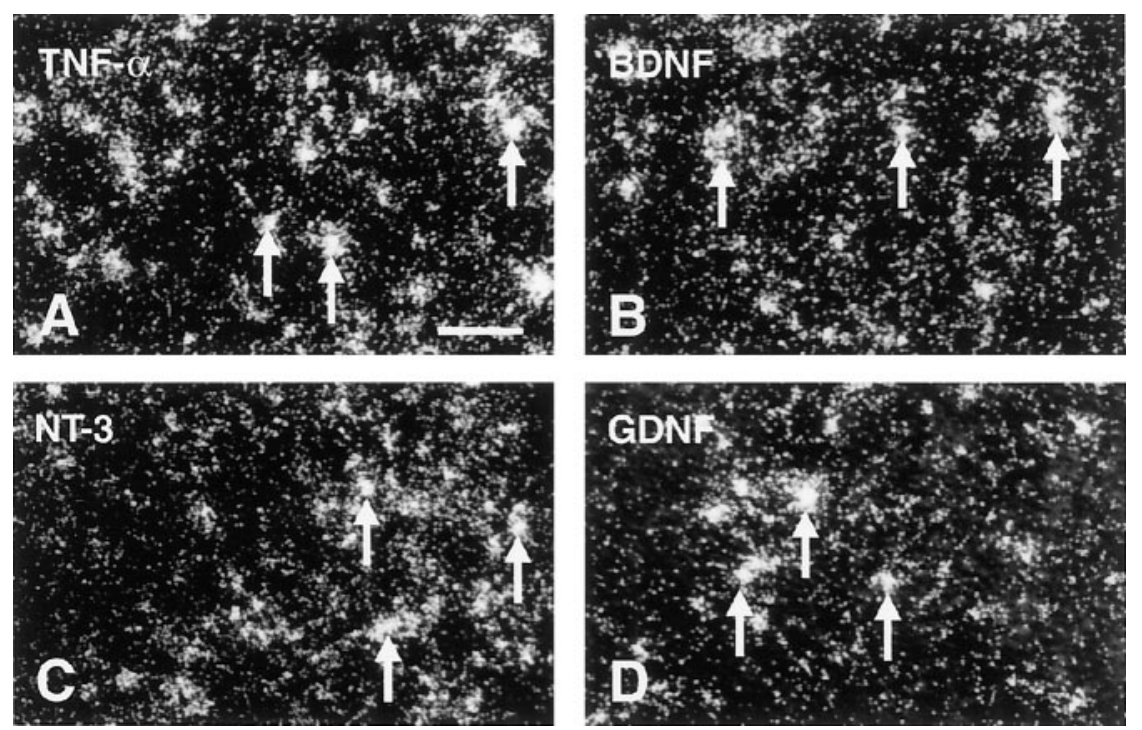

Figure 4. Dark-field micrographs of the mRNA in situ hybridization labeling pattern for $\mathrm{TNF}-\alpha(A)$, BDNF $(B)$, NT-3 $(C)$, and GDNF $(D)$ in draining inguinal lymph nodes from DA rats $14 \mathrm{~d}$ after immunization. Arrows indicate single cells with postive labeling. A, TNF- $\alpha$ mRNA is abundantly expressed in activated lymph node cells. $B, C$, High numbers of BDNF and NT-3 mRNA-positive cells are evident in close adjacent sections of the same area. $D$, Also GDNF mRNApositive cells are present in the same area of the lymph node, but detectable expression is restricted to a smaller number of cells. Scale bar, $0.1 \mathrm{~mm}$.
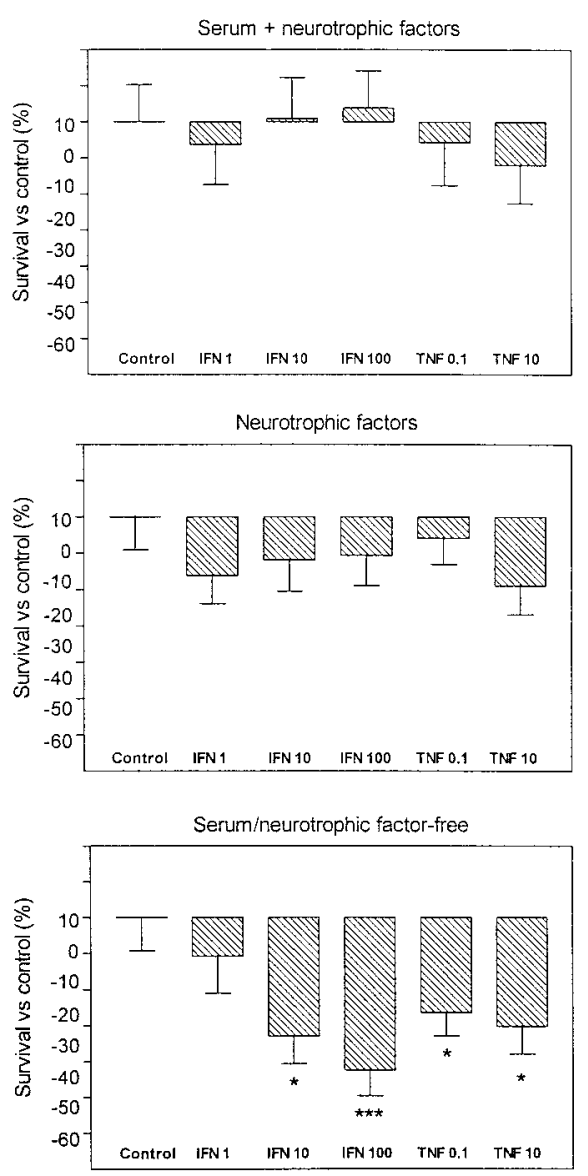

Figure 5. Effects of IFN- $\gamma$ and TNF- $\alpha$ on survival of cultured embryonic motoneurons. Cultures were treated with $\operatorname{IFN}-\gamma(1,10$, or $100 \mathrm{U} / \mathrm{ml})$ or TNF- $\alpha(0.1$ or $10 \mathrm{ng} / \mathrm{ml})$. Cytokine treatment did not have any significant effects on the survival of cells cultured in medium supplemented with serum/neurotrophic factors (top graph) or neurotrophic factors alone (middle graph). In contrast, both IFN- $\gamma$ and TNF- $\alpha$ treatment resulted in a significant, concentration-dependent decrease in numbers of viable cells in cultures deprived of neurotrophic support (bottom graph). Statistical significance was determined with the Kruskall-Wallis test and Dunn's post hoc test against control $\left({ }^{*} p<0.05 ;{ }^{* *} p<0.001\right)$.

does not discernibly change the expression pattern for neurotrophins in the spinal cord, except for a certain accumulation of NT-3-positive NK cells in the meninges.

\section{DISCUSSION}

The results presented herein demonstrate that the survival of mechanically injured spinal motoneurons is significantly increased after active immunization with an encephalitogenic MBP peptide. Thus, although the expected detrimental effects of the autoimmune MBP peptide-directed $T$ cell response in the form of neurological deficits ensued, there was a concurrent pronounced neuroprotective effect of the response. These findings clearly demonstrate that a massive lymphocyte infiltration with highly upregulated levels of proinflammatory cytokines at least temporarily rescues a large proportion of mechanically injured neurons otherwise destined to die. To a certain extent, this requires a reappraisal of the consequences on neurons of immune reactions in primarily inflammatory or infectious diseases of the CNS such as MS, but also in other pathological conditions with inflammatory components, i.e. CNS trauma and cerebrovascular diseases.

This finding is also highly surprising in view of the general concept of inflammatory processes in the CNS. Immunization with the immunogenic MBP peptide leads to an expansion and activation of encephalitogenic $\mathrm{T}$ cells that enter the CNS. The subsequent production of various chemokines on antigen stimulation attracts other cell types such as monocytes and NK cells. As a secondary event to the release of inflammatory cytokines by infiltrating $\mathrm{T}$ cells, production of neurotoxic compounds such as nitric oxide and glutamate agonists is upregulated in resident microglia and monocyte-derived macrophages. A large body of evidence now firmly links these types of highly reactive metabolites with deleterious effects on nerve cells, including motoneurons (Estevez et al., 1998; Urushitani et al., 1998). In addition, avulsion injury alone is mainly characterized by activation of microglia and macrophages, but with virtually no involvement of lymphocytes (Piehl et al., 1999). The neuroprotective effect should therefore reside in some type of direct interaction between lymphocytes and neurons. Thus, it has been suggested that the beneficial effect of transfer of an MBP-specific cell clone after optic nerve crush involves a $\mathrm{T}$ cellmediated induction of a state of "metabolic rest" in lesioned retinal ganglia neurons, which may reduce metabolic needs and prevent energy depletion (Moalem et al., 1999). However, whereas energy depletion can be important for the death of neurons in the penumbra zone surrounding necrotic areas after stroke or stab wounds in the CNS, energy depletion is unlikely to be an important factor in the animal model we have used here. Instead, deprivation of neurotrophic support is implicated as the major determinant for the death of neurons after avulsion injury (Novikov et al., 1995; Kishino et al., 1997).

Three of the most potent survival-promoting agents for motoneurons in vivo and in vitro are NT-3, BDNF, and GDNF 
(Sendtner et al., 1992; Yan et al., 1992; Henderson et al., 1993, 1994; Hughes et al., 1993). Neurotrophins are abundantly expressed in peripheral nerve tissue (Funakoshi et al., 1993), which is an important reason for the high regenerative potential of motoneurons after peripheral nerve lesions. As our results demonstrate, neurotrophic factor expression is relatively low in CNS tissue and is not upregulated in spite of relatively intense glial activation. This concurs with the general concept of a low capacity for CNS tissue in sustaining nerve cell survival and regeneration. In contrast, T and NK (or NK-T) cells present in the CNS during EAE contain very high levels of these neurotrophic factors and therefore constitute an extremely rich source for neurotrophic support to the lesioned motoneurons under these conditions. Furthermore, neurotrophic factors are expressed fairly constitutively in the studied leukocyte populations, perhaps with the exception of the TCRBV8S $2^{+}$cells. Thus, the neuroprotective potential of bystander-recruited leukocytes may exceed that of the diseasedriving, encephalitogenic $\mathrm{T}$ cell population. The fact that in vivo administration of high doses of IFN- $\gamma$ did not increase expression of neurotrophins in the spinal cord also suggests that the direct production of neurotrophins in lymphocytes is relatively more important than local production in activated CNS glial cells.

The notion that immune cells are able to produce neuronal growth factors is not entirely new. Thus, CD4 ${ }^{+} \mathrm{T}$ cells have previously been demonstrated to produce NGF (Ehrhard et al., 1993; Santambrogio et al., 1994) and because of its effects on inflammation, NGF may be considered a neurokine rather than a neurotrophin (Levi-Montalcini et al., 1996). However, because of the very restricted expression of the high-affinity receptor for NGF, trkA, in the CNS, NGF production in lymphocytes may not be particularly relevant as a neuroprotective mechanism for CNS neurons. In contrast, the receptors for BDNF, NT-3, and GDNF have a more widespread expression in the CNS, and exogenous administration of these substances can prevent atrophy and promote regeneration of different classes of CNS neurons after axotomy (Giehl and Tetzlaff, 1996; Kobayashi et al., 1997; Giehl et al., 1998). Production of BDNF in murine T cells (Braun et al., 1999) and human $\mathrm{T}$ and $\mathrm{B}$ cells was recently demonstrated (Kerschensteiner et al., 1999). In addition, BDNF-expressing cells could be detected in perivascular infiltrates in the CNS of patients that had suffered from MS (Kerschensteiner et al., 1999). The trkB receptor is expressed during $\mathrm{T}$ cell development, and BDNF enhances survival of immature thymocytes (Maroder et al., 1996). The fact that certain populations of mature leukocyte populations also express $t r k \mathrm{~B}$ and $t r k \mathrm{C}$ receptors suggests that neurotrophins may also have immunomodulatory effects (Besser and Wank, 1999), although direct evidence for this hypothesis is still lacking. GDNF expression by leukocytes in the CNS has not been demonstrated previously, and the role of this growth factor in the immune system is therefore entirely unknown. Conversely, neurons express receptors for several different cytokines secreted by activated $\mathrm{T}$ cells (Rothwell et al., 1996). In agreement with this, motoneurons respond to TNF- $\alpha$ and IFN- $\gamma$ with upregulation of MHC class I expression (Lindå et al., 1998), which demonstrates that they possess the necessary signal pathways to respond to these classical $\mathrm{T}$ cell-derived cytokines. Mounting evidence suggests that both TNF- $\alpha$ and IFN- $\gamma$ can exert deleterious effects on CNS cells (Louis et al., 1993; Talley et al., 1995; Vartanian et al., 1995). Our results regarding survival of motoneurons in culture demonstrate that TNF- $\alpha$ and IFN- $\gamma$ do not significantly increase the death of embryonic motoneurons cultured in medium supplemented with neurotrophins or serum. In contrast, enhanced cell death was present in cultures of neurotrophin-deprived motoneurons treated with TNF- $\alpha$ and IFN- $\gamma$. The expression of neurotrophins in T and NK cells may therefore be an important mechanism for the protection of CNS neurons from potentially noxious effects of high levels of proinflammatory cytokines. Recently Smith et al. (2000) reported increased death of neurons in the ventral horn during EAE in the LEW rat, which suggests that the balance between the protective and harmful effects of autoimmune reactions in the CNS may be very sensitive. Because Smith et al. (2000) examined a neuronal pool in which the motoneurons constitute a small minority, it is difficult to directly compare the results. One interesting possibility for the discrepancy between the increase in neuronal death reported by them and the neuroprotective effect demonstrated here, however, is that the neuronal loss observed by Smith et al. (2000) is restricted to cell types that are unable to benefit from the increased availability of neurotrophins because of a lack of the relevant receptors. The neurotrophins, except for NGF and GDNF, are among the most potent survival factors for motoneurons, but much less is known about the receptor expression and functional responsiveness to these growth factors for other nerve cell types in the spinal cord. In conclusion, we demonstrate that an autoimmune $\mathrm{T}$ cell reaction supports neuronal survival after mechanical nerve injury and that high levels of the neurotrophic factors NT-3, BDNF, and GDNF are expressed by T and NK cells recruited to the CNS. This may thus constitute a protective mechanism by which immune reactions in the CNS do not lead to detrimental effects on nerve cells. This fact should be considered when immune suppressive therapies are used in CNS diseases such as spinal cord injuries. Hypothetically, a controlled stimulation of an endogenous self-reactive $\mathrm{T}$ cell response may also be used to treat neurodegenerative conditions, such as Alzheimer's dementia or Parkinson's disease, or CNS trauma, in which local delivery of neurotrophic support can retard the loss of nerve cells.

\section{REFERENCES}

Balcarek JM, Cowan NJ (1985) Structure of the mouse glial fibrillary acidic protein gene: implications for the evolution of the intermediate filament multigene family. Nucleic Acids Res 13:5527-5543.

Ben-Nun A, Wekerle H, Cohen IR (1981) The rapid isolation of clonable antigen-specific $\mathrm{T}$ lymphocyte lines capable of mediating autoimmune encephalomyelitis. Eur J Immunol 11:195-199.

Besser M, Wank R (1999) Cutting edge: clonally restricted production of the neurotrophins brain-derived neurotrophic factor and neurotrophin-3 mRNA by human immune cells and Th1/Th2-polarized expression of their receptors. J Immunol 162:6303-6306.

Braun A, Lommatzsch M, Mannsfeldt A, Neuhaus-Steinmetz U, Fischer A, Schnoy N, Lewin GR, Renz H (1999) Cellular sources of enhanced brain-derived neurotrophic factor production in a mouse model of allergic inflammation. Am J Respir Cell Mol Biol 21:537-546.

Camu W, Henderson CE (1992) Purification of embryonic rat motoneurons by panning on a monoclonal antibody to the low-affinity NGF receptor. J Neurosci Methods 44:59-70.

Chandler CE, Parsons LM, Hosang M, Shooter EM (1984) A monoclonal antibody modulates the interaction of nerve growth factor with PC12 cells. J Biol Chem 259:6882-6889.

Dagerlind A, Friberg K, Bean AJ, Hökfelt T (1992) Sensitive mRNA detection using unfixed tissue: combined radioactive and non-radioactive in situ hybridization histochemistry. Histochemistry 98:39-49.

Ehrhard PB, Erb P, Graumann U, Otten U (1993) Expression of nerve growth factor and nerve growth factor receptor tyrosine kinase Trk in activated CD4-positive T-cell clones. Proc Natl Acad Sci USA 90:10984-10988.

Elkabes S, DiCicco-Bloom EM, Black IB (1996) Brain microglia/macrophages express neurotrophins that selectively regulate microglial proliferation and function. J Neurosci 16:2508-2521.

Ericson J, Thor S, Edlund T, Jessell TM, Yamada T (1992) Early stages of motor neuron differentiation revealed by expression of homeobox gene Islet-1. Science 256:1555-1560.

Ernfors P, Ibanez CF, Ebendal T, Olson L, Persson H (1990) Molecular cloning and neurotrophic activities of a protein with structural similarities to nerve growth factor: developmental and topographical expression in the brain. Proc Natl Acad Sci USA 87:5454-5458.

Estevez AG, Spear N, Manuel SM, Radi R, Henderson CE, Barbeito L, Beckman JS (1998) Nitric oxide and superoxide contribute to motor neuron apoptosis induced by trophic factor deprivation. $\mathrm{J}$ Neurosci 18:923-931.

Funakoshi H, Frisén J, Barbany G, Timmusk T, Zachrisson O, Verge VM, Persson H (1993) Differential expression of mRNAs for neurotrophins and their receptors after axotomy of the sciatic nerve. $\mathrm{J}$ Cell Biol 123:455-465.

Giehl KM, Tetzlaff W (1996) BDNF and NT-3, but not NGF, prevent axotomy-induced death of rat corticospinal neurons in vivo. Eur J Neurosci 8:1167-1175.

Giehl KM, Schutte A, Mestres P, Yan Q (1998) The survival-promoting effect of glial cell line-derived neurotrophic factor on axotomized corticospinal neurons in vivo is mediated by an endogenous brain-derived neurotrophic factor mechanism. J Neurosci 18:7351-7360.

Hammarberg H, Risling M, Hökfelt T, Cullheim S, Piehl F (1998) Expression of insulin-like growth factors and corresponding binding proteins 
(IGFBP 1-6) in rat spinal cord and peripheral nerve after axonal injuries. J Comp Neurol 400:57-72.

Hanson MGJ, Shen S, Wiemelt AP, McMorris FA, Barres BA (1998) Cyclic AMP elevation is sufficient to promote the survival of spinal motor neurons in vitro. J Neurosci 18:7361-7371.

Henderson CE, Camu W, Mettling C, Gouin A, Poulsen K, Karihaloo M, Rullamas J, Evans T, McMahon SB, Armanini MP, Berkemeier L, Phillips HS, Rosenthal A (1993) Neurotrophins promote motor neuron survival and are present in embryonic limb bud. Nature 363:266-270.

Henderson CE, Phillips HS, Pollock RA, Davies AM, Lemeulle C, Armanini M, Simmons L, Moffet B, Vandlen RA, Koliatsos VE, Rosenthal A (1994) GDNF: a potent survival factor for motoneurons present in peripheral nerve and muscle. Science 266:1062-1064.

Hughes RA, Sendtner M, Thoenen H (1993) Members of several gene families influence survival of rat motoneurons in vitro and in vivo. J Neurosci Res 36:663-671.

Imrich H, Kugler C, Torres-Nagel N, Dorries R, Hunig T (1995) Prevention and treatment of Lewis rat experimental allergic encephalomyelitis with a monoclonal antibody to the $\mathrm{T}$ cell receptor $\mathrm{V}$ beta 8.2 segment. Eur J Immunol 25:1960-1964.

Kerschensteiner M, Gallmeier E, Behrens L, Leal VV, Misgeld T, Klinkert WE, Kolbeck R, Hoppe E, Oropeza-Wekerle RL, Bartke I, Stadelmann C, Lassmann H, Wekerle H, Hohlfeld R (1999) Activated human T cells, B cells, and monocytes produce brain-derived neurotrophic factor in vitro and in inflammatory brain lesions: a neuroprotective role of inflammation? J Exp Med 189:865-870.

Kishino A, Ishige Y, Tatsuno T, Nakayama C, Noguchi H (1997) BDNF prevents and reverses adult rat motor neuron degeneration and induces axonal outgrowth. Exp Neurol 144:273-86.

Kobayashi NR, Fan DP, Giehl KM, Bedard AM, Wiegand SJ, Tetzlaff W (1997) BDNF and NT-4/5 prevent atrophy of rat rubrospinal neurons after cervical axotomy, stimulate GAP-43 and Talpha1-tubulin mRNA expression, and promote axonal regeneration. J Neurosci 17:9583-9595.

Koliatsos VE, Price WL, Pardo CA, Price DL (1994) Ventral root avulsion: An experimental model of death of adult motor neurons. J Comp Neurol 342:35-44.

Levi-Montalcini R, Skaper S, Dal Toso R, Petrelli L, Leon A (1996) Nerve growth factor: from neurotrophin to neurokine. Trends Neurosci 19:514-520.

Lin LF, Doherty DH, Lile JD, Bektesh S, Collins F (1993) GDNF: a glial cell line-derived neurotrophic factor for midbrain dopaminergic neurons. Science 260:1130-1132.

Lindå H, Hammarberg H, Cullheim S, Levinovitz A, Khademi M, Olsson $\mathrm{T}$ (1998) Expression of MHC class I and beta2-microglobulin in rat spinal motoneurons: regulatory influences by IFN-gamma and axotomy. Exp Neurol 150:282-295.

Louis JC, Magal E, Takayama S, Varon S (1993) CNTF protection of oligodendrocytes against natural and tumor necrosis factor-induced death. Science 259:689-692.

Maisonpierre PC, Le Beau MM, Espinosa Rd, Ip NY, Belluscio L, de la Monte SM, Squinto S, Furth ME, Yancopoulos GD (1991) Human and rat brain-derived neurotrophic factor and neurotrophin-3: gene structures, distributions, and chromosomal localizations. Genomics 10:558-568

Maroder M, Bellavia D, Meco D, Napolitano M, Stigliano A, Alesse E, Vacca A, Giannini G, Frati L, Gulino A, Screpanti I (1996) Expression of trkB neurotrophin receptor during $\mathrm{T}$ cell development. Role of brain derived neurotrophic factor in immature thymocyte survival. J Immunol 157:2864-2872.

Miller SD, Vanderlugt CL, Begolka WS, Pao W, Yauch RL, Neville KL, Katz-Levy Y, Carrizosa A, Kim BS (1997) Persistent infection with Theiler's virus leads to CNS autoimmunity via epitope spreading. Nat Med 3:1133-1136.

Misumi Y, Sohda M, Ikehara Y (1990) Nucleotide and deduced amino acid sequence of rat complement C3. Nucleic Acids Res 18:2178.

Moalem G, Leibowitz-Amit R, Yoles E, Mor F, Cohen I, Schwartz M (1999) Autoimmune T cells protect neurons from secondary degeneration after central nervous system axotomy. Nat Med 5:49-55.

Novikov L, Novikova L, Kellerth JO (1995) Brain-derived neurotrophic factor promotes survival and blocks nitric oxide synthase expression in adult rat spinal motoneurons after ventral root avulsion. Neurosci Lett 200:45-48.
Olsson T, Diener P, Ljungdahl Å, Höjeberg B, van der Meide P, Kristensson K (1992) Facial nerve transection causes expansion of myelin autoreactive $\mathrm{T}$ cells in regional lymph nodes and $\mathrm{T}$ cell homing to the facial nucleus. Autoimmunity 13:117-126.

Olsson T, Sun JB, Solders G, Xiao BG, Höjeberg B, Ekre HP, Link H (1993) Autoreactive $\mathrm{T}$ and $\mathrm{B}$ cell responses to myelin antigens after diagnostic sural nerve biopsy. J Neurol Sci 117:130-139.

Pettinelli CB, McFarlin DE (1981) Adoptive transfer of experimental allergic encephalomyelitis in $\mathrm{SJL} / \mathrm{J}$ mice after in vitro activation of lymph node cells by myelin basic protein: requirement for Lyt $1^{+} 2^{-} \mathrm{T}$ lymphocytes. J Immunol 127:1420-1423.

Piehl F, Tabar G, Cullheim S (1995a) Expression of NMDA receptor mRNAs in rat motoneurons is down-regulated after axotomy. Eur J Neurosci 7:2101-2110.

Piehl F, Ji RR, Cullheim S, Hökfelt T, Lindholm D, Hughes RA (1995b) Fibroblast growth factors regulate calcitonin gene-related peptide mRNA expression in rat motoneurons after lesion and in culture. Eur J Neurosci 7:1739-1750.

Piehl F, Lundberg C, Khademi M, A B, Dahlman I, Lorentzen J, Olsson T (1999) Non-MHC gene regulation of nerve root injury-induced spinal cord inflammation and neuron death. J Neuroimmunol 101:87-97.

Rothwell NJ, Luheshi G, Toulmond S (1996) Cytokines and their receptors in the central nervous system: physiology, pharmacology, and pathology. Pharmacol Ther 69:85-95.

Santambrogio L, Benedetti M, Chao MV, Muzaffar R, Kulig K, Gabellini N, Hochwald G (1994) Nerve growth factor production by lymphocytes. J Immunol 153:4488-4495.

Sendtner M, Holtmann B, Kolbeck R, Thoenen H, Barde Y-A (1992) Brain-derived neurotrophic factor prevents the death of motoneurons in newborn rats after nerve section. Nature 360:757-759.

Serpe C, Kohm A, Huppenbauer C, Sanders V, Jones K (1999) Exacerbation of facial motoneuron loss after facial nerve transection in severe combined immunodeficient (scid) mice. J Neurosci 19:RC7.

Shirai T, Shimizu NS, Horiguchi S, Ito H (1989) Cloning and expression in Escherichia coli of the gene for rat tumor necrosis factor. Agric Biol Chem 53:1733-1736.

Smith T, Groom A, Zhu B, Turski L (2000) Autoimmune encephalomyelitis ameliorated by AMPA antagonists. Nat Med 6:62-66.

Talley AK, Dewhurst S, Perry SW, Dollard SC, Gummuluru S, Fine SM, New D, Epstein LG, Gendelman HE, Gelbard HA (1995) Tumor necrosis factor alpha-induced apoptosis in human neuronal cells: protection by the antioxidant $\mathrm{N}$-acetylcysteine and the genes bcl-2 and crmA. Mol Cell Biol 15:2359-66.

Tanaka S, Suzuki K, Watanabe M, Matsuda A, Tone S, Koike T (1998) Upregulation of a new microglial gene, mrf-1, in response to programmed neuronal cell death and degeneration. J Neurosci 18:6358-6369.

Tsuchida M, Matsumoto Y, Hirahara H, Hanawa H, Tomiyama K, Abo T (1993) Preferential distribution of $\mathrm{V}$ beta 8.2-positive $\mathrm{T}$ cells in the central nervous system of rats with myelin basic protein-induced autoimmune encephalomyelitis. Eur J Immunol 23:2399-2406.

Urushitani M, Shimohama S, Kihara T, Sawada H, Akaike A, Ibi M, Inoue R, Kitamura Y, Taniguchi T, Kimura J (1998) Mechanism of selective motor neuronal death after exposure of spinal cord to glutamate: involvement of glutamate-induced nitric oxide in motor neuron toxicity and nonmotor neuron protection. Ann Neurol 44:796-807.

van der Meide PH, Dubbeld M, Vijverberg K, Kos T, Schellekens H (1986) The purification and characterization of rat gamma interferon by use of two monoclonal antibodies. J Gen Virol 67:1059-1071.

Vartanian T, Li Y, Zhao M, Stefansson K (1995) Interferon-gammainduced oligodendrocyte cell death: implications for the pathogenesis of multiple sclerosis. Mol Med 1:732-743.

Wang W, Olsson T, Kostulas V, Höjeberg B, Ekre H, Link H (1992) Myelin antigen reactive $T$ cells in cerebrovascular diseases. Clin Exp Immunol 88:157-162.

Weissert R, Svenningsson A, Lobell A, de Graaf KL, Andersson R, Olsson $\mathrm{T}$ (1998) Molecular and genetic requirements for preferential recruitment of TCRBV8S2 ${ }^{+} \mathrm{T}$ cells in Lewis rat experimental autoimmune encephalomyelitis. J Immunol 160:681-690.

Yan Q, Elliott J, Snider WD (1992) Brain-derived neurotrophic factor rescues spinal motor neurons from axotomy-induced cell death. Nature 360:753-755. 